\title{
The Role of Capital Structure and Innovation in Corporate Performance Utilizing Firm Size as Moderation: Study of Manufacturing Companies Listed on the IDX
}

\author{
Didik Indarwanta \\ Student of Doctoral Program of Business Administration, Faculty of Administrative Science, Brawijaya \\ University, Jalan MT Haryono No. 163 Malang, East Java - Indonesia, Postal Code 65145 \\ Suhadak, Nila Firdausi Nuzula, and Mohammad Saifi \\ Department of Business Administration, Faculty of Administrative Science, Brawijaya University, Jalan MT \\ Haryono No. 163 Malang, East Java - Indonesia, Postal Code 65145
}

\begin{abstract}
This study examined the effect of capital structure and innovation on the corporate performance of manufacturing companies listed on the IDX. This study examined firm size moderation on the effect of capital structure and innovation on corporate performance. The research sample was manufacturing companies listed on the Indonesia Stock Exchange in the 2013 - 2017 period. The sampling method utilized was the purposive sampling technique. Data analysis used WarpPLS. The research result exhibited capital structure has a significant effect on innovation. Capital structure and innovation have a significant effect on corporate performance. Innovation has a significant effect on corporate performance. Firm size as a moderating variable strengthened the effect of innovation on corporate performance. Research result exhibits new findings as there is no research utilizing firm size as moderation on the effect of innovation on corporate performance. Research result exhibited that firm size does not moderate capital structure influence on corporate performance.
\end{abstract}

Keywords: Capital structure, innovation, firm size, corporate performance.

DOI: $10.7176 /$ RJFA/11-4-01

Publication date: February $29^{\text {th }} 2020$

\section{INTRODUCTION}

Companies are challenged to survive in the era of global competition. The company's performance is the main key to survive in the global era. One of the factors that determine an organization's business performance in the global era is innovation. Rapid technological advances and high levels of competition demand continuous innovation. High innovation would increase the company's ability to create high-quality products or services. Innovations made by a company are unique resources. Penrose (2009) states that companies possessing unique resources would produce high performance. Based on Penrose's view, an increasingly innovative company will ultimately increase its competitive advantage. In turn, it would improve company performance.

Fund sources to finance innovation are debt or equity. The proportion of the use of debt and equity in financing its investment is called capital structure. Regarding funding for innovation, the company considers the risk of shareholders. Shareholders would tend to refuse projects should investments or innovations are fully funded with company internal funds because the risk borne by shareholders is even greater. The risk of failure will be further reduced should the funding uses a combination of internal and external funding (leverage) or fully uses external funding as the risk will be transferred to creditors.

Research on innovation in the financial context is still limited. This study aimed to examine the capital structure as a determinant of innovation and its influence on corporate performance. This study examined the effect of capital structure and innovation on corporate performance with firm size as a moderator variable. This research was conducted on manufacturing companies that go-public on the Indonesia Stock Exchange in 2013 - 2017 period. The Manufacturing Industry has a very large contribution to GDP in Indonesia. Therefore it is necessary to conduct a study related to the effect of capital structure and innovation on corporate performance in manufacturing companies that go public on the Indonesia Stock Exchange.

\section{LITERATURE REVIEW}

2.1. Tax Shield hypothesis (Modigliani Miller, 1963),

In 1963, Modigliani's Miller article, following the MM theory of 1958, changed the assumption that there was a tax on corporate income. Modigliani Miller stated that capital structure can improve company performance. Modigliani Miller concluded that with taxes, the use of debt will improve company performance because the cost of debt interest is the cost of reducing tax payments. 


\subsection{Agency Theory}

Capital structure policies can prevent agents from opportunistic behavior and personal interests. Jensen (1986) states that debt creation, renders the managers to be bound by obligations/promises to pay future cash flows. On an event default occurs or the manager is unable to fulfill his obligations, it would increase bankruptcy risk. In turn, it will destroy the manager's career. A company manager would actively attempt to avoid said risk. Threats caused by defaults on debt payments can serve as a driver to make the organization more effective. In other words, debt can reduce agency costs and ultimately improve company performance.

\subsection{Resources Based View (Penrose, 2009)}

The Resource-based View states that companies possessing unique resources would produce high performance. Innovations made by the company are unique resources. A higher innovation rate would increase company value. Resource-Based View views company resources and capabilities as a major factor of competitive advantage and company performance. This concept provides a theoretical framework in determining resources and capabilities that provide a competitive advantage and ultimately improve company performance (Wernerfelt, 1984).

\subsection{Capital structure}

Capital structure is permanent financing consisting of long-term debt, preferred shares, and shareholder capital (Weston and Copeland, 1996). The capital structure exhibits the proportion of the use of debt to finance its investment. Investors could determine the balance between risk and return on investment. The purpose of capital structure management is to combine the sources of funds used by the company to finance operations to minimize capital costs and maximize stock prices.

\subsection{Innovation}

Schumpeter divides innovation into five types (OECD, 1997), namely the introduction of new products, process innovation, opening new markets, developing sources of raw materials or other new inputs, and changing industrial organizations. Innovations with financial aspects are often associated with research and development costs. Damanpour and Wischnevsky (2006), stated that the commitment of business organizations in measuring innovation utilizes $R \& D$ costs.

\subsection{Corporate performance}

The company's performance is the result of activities and returns on investment within a certain period (Tabari et al. 2013). Company performance is used for the evaluation and decision making of certain parties. Performance evaluation can be divided into two categories, namely based on the size of accounting information (financial performance) and market information (firm value). Financial performance is the result of the company within a certain period with reference to established standards. Firm value is the same as the market value of debt and equity, minus cash and cash equivalents of the company.

\subsection{Firm size}

Firm Size is a picture of a company exhibited in total assets (Vithessonthi, 2015) and or total company sales (Moh'd et al., 1995). Most of the literature exhibits that larger companies will have a resource advantage compared to smaller companies. Large companies possess a competitive advantage over their competitors and achieve superior performance (Vithessonthi, 2015).

\section{HYPOTHESIS}

Based on theoretical and empirical studies, the following hypotheses were formulated:

H1. Capital structure influences Innovation

H2. Capital structure influences corporate performance

H3. Innovation influences corporate performance

H4. Firm size moderates the influence of capital structure on corporate performance

H5. Firm size moderates the influence of innovation on corporate performance 


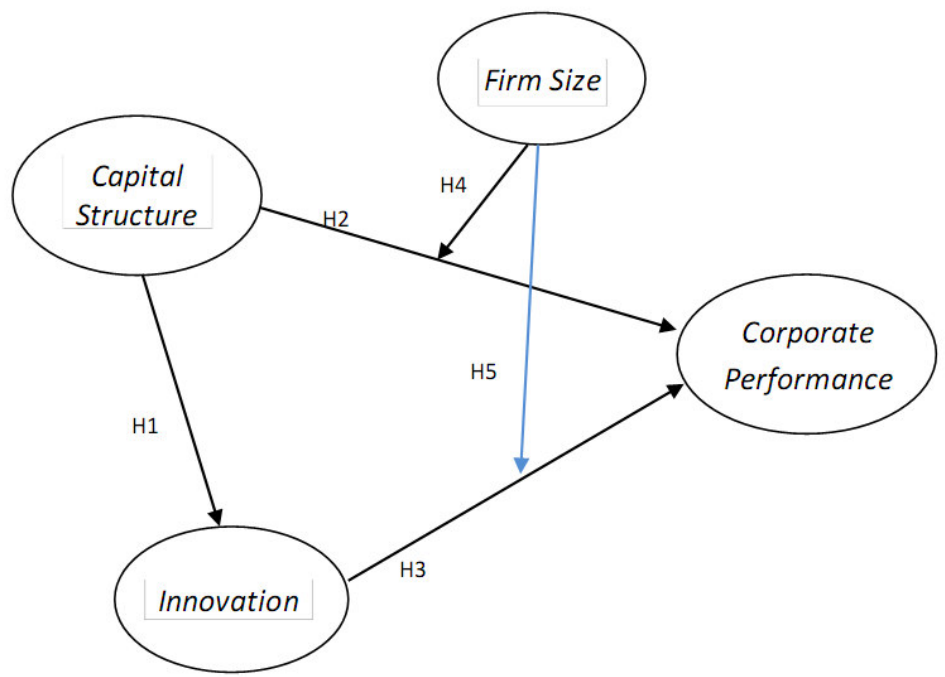

Figure 1 - Hypothesis Model

\section{RESEARCH METHODS}

\subsection{Data collection and sample}

The population of this research was all manufacturing companies Go-Public on the Indonesia Stock Exchange in the 2013-2017 period. This study used panel data with $n$ data total of 140. The sampling method utilized was the purposive sampling technique, where samples were taken based on criteria that have been formulated in advance. The sample criteria are described as follows:

1. Manufacturing companies listed on the Indonesia Stock Exchange.

2. Manufacturing companies that have published financial reports continuously during the study period 2013 - 2017.

3. Manufacturing companies that continuously generated profit during the study period $2013-2017$.

4. Manufacturing companies that provide data on research and development (R\&D) costs during the research period $2013-2017$.

\subsection{Measurement}

The capital structure variable is proxied by Total Debt Ratio (Sheikh, 2012, Horne and John, 2012), and Debt Equity Ratio (Shyu, 2013, Horne and John, 2012).

The innovation variable is proxied by $\mathrm{R} \& \mathrm{D} / \mathrm{S}$ (ratio of research and development costs to sales) (Mohd et al, 1998, Titman and Wessels, 1998), and R \& D / A (ratio of research and development costs to Assets) (Kallapur and Trombley, 1999, 2001).

Corporate performance variables are proxied by ROA (Yadav and Salim, 2012, Tifow and Sayilir, 2015, Detthamrong et al. 2017), ROE (Salim and Yadav, 2012, Tifow and Sayilir, 2015, Detthamrong et al. 2017), Tobin's Q companies (Mollah, 2012, Salim and Yadav, 2012, Tifow and Sayilir, 2015).

Firm size variables are proxied by total assets (Vithessonthi, 2015), and total company sales (Moh'd et al., 1995, Bringham and Houston., 2006).

\subsection{Data analysis}

The analysis of this study used descriptive statistical analysis and inductive statistical analysis. Descriptive statistics were used to describe the research variables, while inferential statistics were used to test the effect of the variables in this study. Researchers used the WarpPLS statistical tool.

\section{RESEARCH FINDINGS}

5.1. Model Goodness of Fit and Model Quality Index

The model ought to possess a good Goodness of Fit before interpreting the results of the hypothesis assessment. There are 10 (ten) sizes of Model Fit and Quality Indices in the WarpPLS analysis to measure the quality of structural models (Solimun et al., 2017). The feasibility test and the quality value of the model and criteria are presented in Table 1. 
Table 1. Model Goodness of Fit and Model Quality Index

\begin{tabular}{|c|l|c|c|}
\hline No. & \multicolumn{1}{|c|}{ Model Goodness of Fit and Model Quality Index } & Criteria & Result \\
\hline 1 & Average path coefficient (APC) & $\mathrm{p}<0.05$ & $0.385,(\mathrm{P}<0.001)$ \\
\hline 2 & Average R-squared (ARS) & $\mathrm{p}<0.05$ & $\begin{array}{c}0.636, \\
(\mathrm{p}<0.001)\end{array}$ \\
\hline 3 & Average adjusted R-squared (AARS) & $\begin{array}{c}0.632 \\
(\mathrm{p}<0.001)\end{array}$ \\
\hline 4 & Average block VIF (AVIF) & acceptable $\leq 5$ ideal $\leq 3.3$ & 3.079 \\
\hline 5 & Average full collinearity VIF (AFVIF) & acceptable $\leq 5$ ideal $\leq 3.3$ & 2.190 \\
\hline 6 & Tenenhaus GoF (GoF) & $\begin{array}{c}\text { small } \geq 0.1 \\
\text { medium } \geq 0.25 \\
\text { large } \geq 0.36\end{array}$ & 0.781 \\
\hline 7 & Sympson's paradox ratio (SPR) & $\begin{array}{c}\text { acceptable } \geq 0.7 \\
\text { ideal }=1\end{array}$ & 0.800 \\
\hline 8 & R-squared contribution ratio (RSCR) & $\begin{array}{c}\text { acceptable } \geq 0.9 \\
\text { ideal }=1\end{array}$ & 0.971 \\
\hline 9 & Statistical suppression ratio (SSR) & acceptable $\geq 0.7$ & 1.000 \\
\hline 10 & Nonlinear bivariate causality direction ratio (NLBCDR) & acceptable $\geq 0.7$ & 1.000 \\
\hline
\end{tabular}

In Table 1., tests on all the eligibility criteria and quality index have been met. This exhibits that the structural model of the analysis results is feasible to be interpreted.

Hypothesis Assessment

Hypothesis testing was used to assess the significance of the relationship between variables by determining the p-value. If the p-value is smaller than the 0.05 error level, it can be concluded that there is a significant relationship between variables. Path coefficients and hypothesis assessment are presented in Table 2 .

Table 2. Path Coefficients for Direct Influence and Moderation

\begin{tabular}{|c|l|r|r|c|}
\hline No. & \multicolumn{1}{|c|}{ Inter-Variable Relationship } & Coefficient & P-value & Description \\
\hline 1 & Capital Structure $\rightarrow$ Innovation & 0.626 & $<0.001$ & Significant \\
\hline 2 & Capital Structure $\rightarrow$ Corporate performance & 0.221 & 0.003 & Significant \\
\hline 3 & Innovation $\rightarrow$ Corporate performance & 0.802 & $<0.001$ & Significant \\
\hline \multicolumn{5}{|c|}{ Moderation Variable Assessment } \\
\hline 4 & $\begin{array}{l}\text { Firm size as moderating variable: Capital } \\
\text { Structure } \rightarrow \text { Corporate performance }\end{array}$ & -0.061 & 0.233 & $\begin{array}{c}\text { Insignificant } \\
\text { (Not Moderating) }\end{array}$ \\
\hline 5 & $\begin{array}{l}\text { Firm size as moderating variable: Innovation } \\
\rightarrow \text { Corporate performance }\end{array}$ & 0.215 & 0.004 & $\begin{array}{c}\text { Insignificant } \\
\text { (Moderating) }\end{array}$ \\
\hline
\end{tabular}

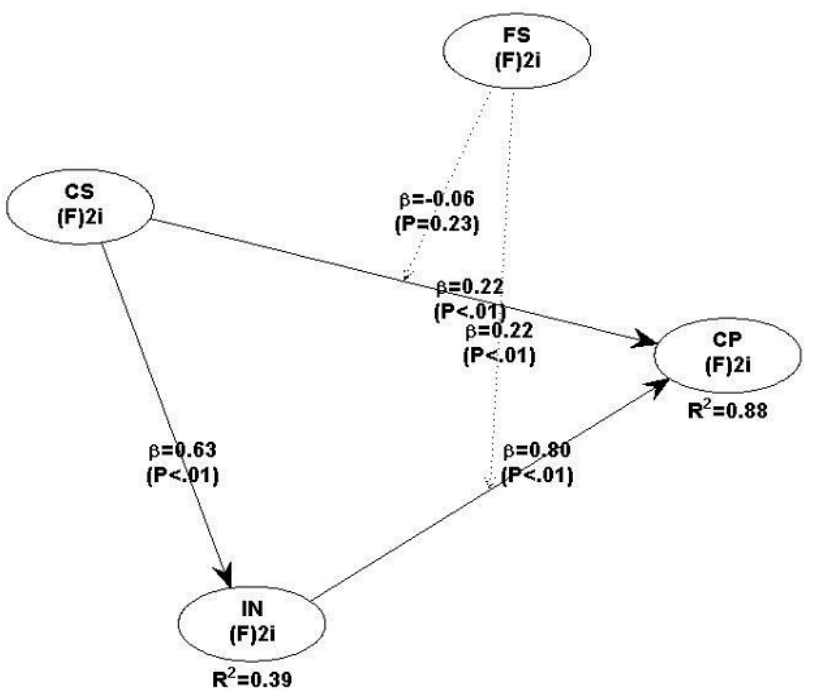

Figure 2 - Final Structural Model

5.2. Hypothesis Assessment

This research formulated 6 hypotheses. Hypothesis assessment was conducted by comparing the p-value with an 
alpha of $5 \%$. If the $p$-value is $\leq 0.05$, the hypothesis is accepted and if $p$ value $>0.05$, the hypothesis is rejected.

1) Hypothesis 1 states that capital structure influences innovation. The results (Table 2) exhibited that $\mathrm{p}-$ value $=<0.001(<0.05)$, therefore hypothesis 1 is accepted. The coefficient marked positive indicates that capital structure has a significant positive effect on innovation.

2) Hypothesis 2 states that capital structure influences corporate performance. The results exhibited that $p$ value $=0.003(<0.05)$, therefore hypothesis 2 is accepted. The coefficient marked positive indicates that capital structure has a significant positive effect on corporate performance.

3) Hypothesis 3 states that innovation influences corporate performance. The results exhibited that $p$-value $=<0.001(<0.05)$ therefore hypothesis 3 is accepted. The coefficient marked positive indicates that innovation has a significant positive effect on corporate performance.

4) Hypothesis 4 states that firm size moderates the effect of capital structure on corporate performance. The results exhibited that $\mathrm{p}$-value $=0.233(>0.05)$ and coefficient of -0.061 therefore hypothesis 4 is rejected. It indicates that firm size does not moderate the effect of capital structure on corporate performance. The coefficient marked negative is different capital structure influence on corporate performance coefficient, indicating that the firm size weakens the effect of capital structure on corporate performance.

5) Hypothesis 5 states that firm size moderates the effect of innovation on corporate performance. The results exhibited that $\mathrm{p}$-value $=0.004(<0.05)$, therefore the hypothesis 5 is accepted. The coefficient marked positive is the same as the innovation influence on corporate performance coefficient, indicating that firm size strengthens the effect of innovation on corporate performance.

\section{DISCUSSION}

The research result exhibited that capital structure had a significant positive effect on innovation. The results of this study support Li and Simerly (2002) that capital structure has a significant positive effect on innovation. When in a stable environment, a high level of debt positively influences innovation.

The findings also exhibited that capital structure influences corporate performance. This finding supports Detthamrong et al. (2017), Saifi et al. (2016), which states that there is a significant positive influence between capital structure on company performance. The findings also support the MM theory (Modigliani Miller, 1963), which states that capital structure influences corporate performance. Leverage can increase company value because of tax protection.

This study proves that innovation influences corporate performance. The research results support Ruiqi et al. (2017) research exhibiting that expenditure on research and development is positively related to the company's future performance. This finding strengthens the theory of innovation from the perspective of Resources Based View that the company continues to develop innovation internally. Innovation becomes an important determinant of corporate performance. It exhibited that the innovation variable is the dominant variable affecting corporate performance.

In addition, this study found that firm size does not moderate the effect of capital structure on corporate performance. It indicates that firm size does not strengthen or weaken the effect of capital structure on corporate performance. Related to hypothesis 2 , that debt can increase the value of the company due to tax protection, the cost of debt is cheaper than the cost of issuing shares. Therefore the size of the company is not a concern in the effect of capital structure on corporate performance.

The final finding is that firm size reinforces the effect of capital structure on corporate performance. This finding is in line with the resource-based view (Penrose, 2009), stating that larger companies will have greater resources, knowledge, and capabilities. Therefore, large companies may have a competitive advantage over their competitors and achieve superior performance. With the moderation of firm size, the effect of innovation on corporate performance will be stronger.

\section{CONCLUSION}

The main objective of this research is to develop an understanding of the importance of innovation in contributing to corporate performance, especially in go public manufacturing companies in Indonesia during the 2013-2017 period. The study included firm size variables as moderation variables, previous studies have not discussed firm size moderation on the effect of innovation on company performance.

Based on the findings, there is a direct influence and the influence of moderation between variables. First, capital structure has a significant influence on innovation. Second, capital structure has a significant influence on corporate performance. Third, innovation has a significant influence on corporate performance. Fourth, firm size does not moderate the effect of capital structure on corporate performance. And finally, the firm size strengthens the effect of innovation on corporate performance.

The practical implication is that the company is expected to continuously be able to improve its competitiveness through innovation. This finding exhibits that innovation is crucial in improving corporate performance. It is exhibited that innovation is the dominant variable affecting corporate performance with a 
positive relationship direction.

This study has limitations, as a reference for further researches. This research emphasizes R\&D cost data as a proxy choice for measuring innovation. However, innovation can also be determined through innovation process and output. The future research needs to add an innovation proxy other than R\&D to the innovation variable.

\section{References}

Brigham dan Houston. 2006. Manajemen Keuangan. Edisi kedelapan, Buku 2. Jakarta, Erlangga.

Detthamrong, Umawadee., Chancharat, Nongnit., Vithessonthi, Chaiporn. 2017. Corporate governance, capital structure and firm performance: Evidence from Thailand. Research in International Business and Finance 42, $689-709$.

Horne, James C. Van dan John M. Wachowicz Jr. 2012. Prinsip-prinsip Manajemen Keuangan : Fundamentals of Financial Management. Edisi 13, Buku 1. Jakarta : Salemba Empat.

Jensen, M.C., \& Meckling, W.H. 1986. Agency Cost of Free Cash Flow, Corporate Finance, and Takeovers, American Economic Review, Vol.76, No. 2, pp. 323-329.

Kallapur, S \& Trombley, Mark A. 1999. The Association Between Investment Opportunity Set Proxies and Realized Growth. Journal of Business Finance \& Accounting. 26 (3 \& 4): 505-519.

Kallapur, S \& Trombley, Mark A. 2001. The investment opportunity set: determinants, consequences, and measurement. Managerial Finance, Vol. 27 No 3 pp. 3 - 15.

Li, Mingfang., Simerly, Roy L., 2002. Environmental Dynamism, Capital Structure And Innovation: An Empirical Test. The International Journal of Organizational Analysis, Vol. 10 pp. $156-171$

Modigliani, F., Miller, M. 1963. Corporate Income Taxes and The Cost of Capital: A Correction. American Economic Review. Vol. 53: 433 - 443.

Moh'd, Mahmoud A., Perry, L. G., Rimbey, James N. 1995. An Investigation of the Dynamic Relationship between Agency Theory and Dividend Policy. Financial Review, Vol. 30 No. 2 pp. 367-385

Moh'd, Mahmoud A., Perry, L. G., Rimbey, James N. 1998. The impact of ownership structure on corporate debt policy: a Time-Series Cross-Sectional Analysis. The Financial Review 33.85-98.

Mollah, A.S., Farooque, Omar Al, Karim, Wares. 2012. Ownership Structure, Capital Structure, and Firm Performance Finance. Studies in Economics and Finance Vol. 29 No. 4, pp. 301-319.

OECD (Organization for Economic and Cooperation Development). 1997. The Oslo Manual: Proposed Guidelines for Collecting and Interpreting Technological Innovation Data. Paris, OECD.

Penrose, E. T. (2009). The Theory of the Growth of the Firm. Fourth edition, revised edition. Oxford University Press Inc., New York.

Ruiqi, W., Wang, Fangjun., Xu, Luying., Yuan, Changhong. 2017. R\&D expenditures, ultimate ownership and future performance: Evidence from China. Journal of Business Research 71. pp.47-54.

Saifi M, Suhadak, Rahayu SM, Handayani SR. 2016. The Effect of Corporate Governance and Investment Opportunity Set on Capital Structure, Dividend Policy, and Firm Performance (A Study on Go-Public Manufacturing Companies in Indonesia Stock Exchange). International Journal of Management and Administrative Sciences (IJMAS). Vol. 3, No. 02, (53-63)

Salim, Mahfuzah., Yadav, Raj. 2012. Capital Structure and Firm Performance: Evidence from Malaysian Listed Companies. International Congress on Interdisciplinary Business and Social Science. Procedia - Social and Behavioral Sciences 65. h.156-166

Sheikh, N.A., Wang, Z. 2012. Effecs of corporate governance on Capital Structure: Empirical Evidence from Pakistan. Corporate Governance. 12(5): 629-641.

Shyu, Jonchi. 2013. Ownership structure, capital structure, and performance of group affiliation: Evidence from Taiwanese group-affiliated firms, Managerial Finance, Vol. 39 Issue: 4, pp.404-420.

Solimun., Fernandes AAR., Nurjannah. 2017. Metode Statistika Multivariat: Pemodelan Persamaan Struktural (SEM). Pendekatan WarpPLS. UB Press.

Tabari, Naser Ali Y., Nasrollahi, Mohammad., Emamgholipour, Milad., Mansourinia, Elham. 2013. Relationship between Capital Cost and Market Measures of Corporate Performance Evaluation: Evidence from the Tehran Stock Exchange. International Research Journal of Applied and Basic Scien. Vol, 4 (5): 1221-1230.

Tifow, Abdulkadir Ali., Sayilir, Ozlem. 2015, Capital Structure And Firm Performance: An Analysis of Manufacturing Firms in Turkey, Eurasian Journal of Business and Management, 3(4) h: 13 - 22.

Titman, S., dan Wessels, R., 1988. The Determinant of Capital Structure Choice. Journal of Finance. 43 (1):1-19.

Vithessonthi, C., Tongurai, J. 2013. The effect of firm size on the leverage-performance relationship during the financial crisis of 2007-2009. Journal of Multinational Financial Management. Vol. 29, p 1-29. https://doi.org/10.1016/j.mulfin.2014.11.001.

Wernerfelt, B. (1984). a Resource-Based View of the Firm. Strategic Management Journal, 5, 171-180. http://doi.org/10.1002/smj.4250050207 